Araştırma Makalesi / Research Article

PUBLIC SECTOR REFORMS AND CONTEMPORARY REFORM CHALLENGES TO SUSTAINABLE DEVELOPMENT IN AFRICA

\title{
Billy AGWANDA1
}

\begin{abstract}
Since the 1980s, African countries have been undertaking reforms in the public sector to establish effective and efficient public sector management and capacity. This is founded on the need to thrust Africa into sustainable growth through improved public management structures and good governance. These initiatives fall under global drive on sustainable development spearheaded by national governments and international organizations to achieve national and millennium development goals and, address challenges such as poverty, high unemployment rates and quality access to public services and goods. This paper examines the evolution of the African public sector reforms and the challenges that have hindered African states in their attempt to restructure the public sector. It argues that there is need for comprehensive adoption and implementation of organizational mechanisms such as privatization, contractual performance and decentralization as restorative measures in improving public service delivery through enhanced accountability and integrity in the public sector.
\end{abstract}

Keywords: Africa, Public Sector Reforms, Sustainable Development, Decentralization, Corruption, Accountability

\section{Introduction}

The public sector is always the fundamental platform through which citizens assess the performance of their governments. However, it is noteworthy that before Africa was colonised, the public sector was not properly structured largely because of the socio-economic and political organization of the African societies. The precolonial era in the continent was one that involved simple interactions based on personal relations. Goods and services were exchanged through a system of barter trade that made individuals dependent of their social relations with other members of the society. But, with the emergence of colonial powers in the continent, the African socio-economic and political structure was extensively transformed. Most societies lost their land to the new settlers and forced to live in concentrated centres where they could easily be exploited for their labour. Additionally, new forms of medicine, education, political organization and economic structures were introduced. These rapid changes in structure of the society all-together led to the emergence of the public sector which fundamentally

1 PhD Student, İstanbul Commerce University, Social Sciences Institute, Political Science and International Relations, agwandabilly@gmail.com, orcid.org/0000-0002-8915-6057 
was to facilitate easier exploitation of the continent and societal conformity to the new colonial masters who were in-charge of public services and goods. By weakening self-reliance of the African masses, vast majority of citizens in the African continent became dependent on the public sector to access goods and services.

As such, by the end of colonialism, the public sector became a key feature of the new independent African continent. With the African masses having suffered extensively from colonialization ranging from por access to public goods and services as well as discrimination in accessing these public goods and services by the colonial powers, the new independent African governments embarked on reforming the public sector to increase the quality and capacity of access of public goods and services. This article therefore attempts to trace the stages through which the African public sector has undergone reforms purposely to improve public sector access to goods and services. Secondly, the paper aims at examining the contemporary challenges to the African public sector that has undermined previous and contemporary attempts. This paper will contribute to the existing literature on public sector reforms in Africa by examining some of the contemporary issues that continue to undermine the efficiency and effectiveness of the public sector as the continent strives to achieve sustainable development goals. The paper also argues that for the public sector to benefit from these reform initiatives, African states need to strengthen the capacities off their political economies and adopt new system of governance in the form of decentralization both in her politics and public sector.

\section{Theoretical Framework}

This paper has adopted the open systems theory drawn from public administration as the underpinning theoretical framework through which African public sector reforms are advanced. The open systems theory provides a framework for understanding the conceptualization of the mechanisms that strive to improve the administrative actions or reforms necessary for the realization of policies and objectives of in public sectors. In the African context, Mokhothu (2006: 2) argues that the policy reforms in the public sector are purposely to improve access and quality of public services and goods. As such, this theory is in tandem with the efforts taken by African government to strengthen the public sector and enhance public development that meet public interests. According to Hood (1991), there are key indicators of an open system such as: the capacity of a given system to obtain inputs from the existing environment; ability to transform such inputs into outputs; and, discharge the outputs back into the environment. The interaction between input, output and the surrounding environment therefore forms the basic pillars of open systems.

Dzimbiri (2009: 78) while contextualizing open systems within organizational paradigms, additionally identifies sub-systems such as managerial, production, adaptive, maintenance, and supportive sub-systems. These systems are responsible for the planning and control of the whole system; execution of basic tasks; adaptation to changes in the surrounding environment; ensuring organizational stability and, procurement of inputs and disposal of outputs respectively. As such, the open systems theory outlines the relevance of open interaction and flow of information between and among different sectors. The theory therefore provides a connection with this study by providing an understanding of the relevance on why institutions in the public sector should embrace open organizational systems to enhance public sector delivery of goods and services. This can be achieved because of the capacity of an open system to 
minimise deterrents of effective public sector performance such as lack of transparency, accountability, integrity and centralization of power in public sector.

In the public sector reforms in Africa, the open system was conceived under the guise of New Public Management that emphasized on citizens and accountability from public institutions. This doctrine of public management was adopted in African public sector reforms having dominated public administration reforms in most of the OECD nations ((Hood, 1991; Pollitt, 1993; Ridley, 1996). The New Public Management pushed states towards open systems of public sector management in the form of market-based public service management unlike the traditional public management that stressed bureaucratic hierarchies, centralization and direct control of the public sector by the government. New Public Management therefore adopted open systems in public service sector to enhance efficiency through competition that is responsive to the needs of people and outcome-oriented. As such, the open system model of the New Public Management introduced competition in public sector to lower costs; empowered managers to conduct themselves according to ethos of professional management in the public sector; decentralized the public sector for efficient management; streamlined the labour in public sector to reduce costs; and, adopted private sector management techniques in public sector to increase flexibility in making decisions (Hood, 1991).

\section{Public Sector Reforms}

According to Farazmand (1999: 513), there is lack of consensus among scholars regarding the definition of reforms because it holds different understandings to politicians, academics and administrators. Nonetheless, Farazmand (1999) conceives reforms as targeted efforts aimed at modernizing and transforming the society using administrative systems as the instruments of social and economic change. Bayat et. al. (1994: 250) defines reforms as targeted attempts to trigger fundamental changes in the structure of public administration through expansive changes aimed at streamlining administrative systems. Zhang et. al. (2001: 4), argues that reform is a government adjustment process to restructure its internal and external environment ranging from its management styles, procedures, culture, structure and functions to improve the effectiveness of governance.

Corkery et. al. (1998: 83), connotes public sector reforms as changes in the processes, procedures and policies in public administration with or without underlying political connotations. Omoyefa (2008: 18) adopts a radical stance by arguing that public sector reforms as the complete overhaul of the public administrative structure to establish real efficiency, financial discipline, effectiveness and competency in the management of public sector to address the needs of the public in a rapidly transforming socio-economic and political environment.

Schacter (2000), defines public sector reforms as strengthening of management of public sector affairs. Among other key measures, these reforms involve limiting misuse of public resources, removing complex and unnecessary bureaucracies and, addressing the duplication of duties or responsibilities. Additionally, the African Development Bank (2005) connotes that public sector reforms are procedures, actions or practices that emphasize on boosting the capacity of public institutions in executing accountable, effective and efficient 
public policies founded on legal frameworks of public policies. These policies touch on decentralization; reforms in the civil service; accountability; fiscal and financial reforms; and, reforms on law and the judiciary. Through this, the public sector reforms therefore, became the primary avenue through which African governments could address developmental needs of the society through better or enhanced access to public services as a crucial component of growth and development of African economies. Among other important tenets, good public services which is derived from reforms in the public sector, involve access to services such as healthcare, education, transport and infrastructure systems, security and the establishment of an atmosphere that advances economic growth and safeguards human rights and freedoms.

\subsection{Understanding Public Sector Reforms in Africa}

African governments often use the public sector as the baseline for adopting, advancing and implementing national development goals (Fatile, 2010). According to Haque (2002), public sector anchors economic development in African countries by establishing the appropriate conditions through which economic sectors can attain optimum performance. The public sector identifies the potential sectors that can steer growth through the provision of public goods and services that reflect public interests and needs. Prior to the attainment of political independence across the continent from the 1950s and onwards, the public sector existed but notably, it was one that did not strive to reflect the interests of the larger African public but rather, the interests of the minority colonial rulers. It is on this account that no studies on public sector reforms in Africa can be found during the colonial period. Olowu (1992: 229) notes that transforming the public sector therefore became necessary for post-colonial African states to accommodate new developmental needs. This would empower the new independent states to undertake key intensive social reforms that would improve the quality of lives for the African masses. It therefore fell upon the post-colonial African states to reform the public sector and address the challenges that faced African masses before and after political independence.

However, at independence, the African public sector continued to remain weak as it failed to address the fundamental public development needs. Studies by Garnham (1990: 157) and Haque (2001: 69) linked the weakness of the public sectors in Africa to issues pertaining to lack of accountability, government irresponsiveness to public development needs, centralization of power, corruption and state secrecy on public matters such as resource allocation and use. Notably, African states at independence opted to adopt one-party political systems as a way of establishing national unity following centuries of chronic European colonization that divided African societies into ethnic cocoons. However, gradual political power competitions took centre-stage leading to emergence of deeply rooted systems of marginalization (Deng, 2001: 185). Different sections of African societies were marginalized based on their ethnic orientations and religious ideals. Instead of the anticipated democratic regimes after independence, personal rule spread all over the continent. This led to emergence of fragile states characterized by military coups. As such, from the 1960 s onwards, Africa was preoccupied with sociopolitical and ethnic conflicts.

The international structure in the 1980s presented a plethora of challenges to Africa fundamentally because of the increase in international prices for oil, extreme droughts in various parts of the continent, increase in rates of population growth, rising external debts and a steady decline in price of agricultural raw materials. As such, in exchange for foreign aid and investments, western powers 
begun piling more pressures on African countries to adopt liberalization in both economy and politics. These demands from external actors to African states, marked the onset of reforms aimed at improving equity, efficiency and access to quality public services by the masses (Economic Commission for Africa, 2004). The introduction of structural adjustment programmes emphasized on establishing macro-economic stability, reducing government expenditure, cuttingdown on government deficit expenditure and lowering the rates of inflation. However, these adjustments also meant that government retreated from providing essential public services such as education, access to affordable housing and healthcare at the detriment of African masses. The 1980s therefore marked a turning point in Africa's approach to her public sector management through debates concerning the role of good governance in improving the public sector and enhance sustainable and good public service delivery.

By the 1990s, African governments came under sustained pressure from both domestic and international actors for the liberalization of economic and political space through the introduction of democratic systems (Gordon, 1996: 1531). Democratic governance was advanced to transform the role of government in establishing favourable conditions that would enhance effective public service by promoting quality of public sector service, competence and efficiency. It was these sorts of concerns that advanced the debate surrounding public sector reforms as a means of addressing poor governance and the role it occupies in the development challenges facing the continent. The World Bank which was at the forefront of advancing new reforms in African public sectors, emphasized on better public management through accountability to the public as a means of instilling responsibility of the government to the needs of the public. Cognizant of this, the World Bank established a special Public Sector Board (PSB) constituted of 12 members under the direction of the top directors at World Bank to steer African governments towards embracing more transparency, accountability and efficiency in all public sector institutions (Mukandala, 2000).

\subsection{Public Sector Reform Waves in Africa}

The efforts to align Africa into the global development agenda has seen several African countries become involved in public sector reforms through actions that are either theoretically and, or, practically aimed at enhancing practices of good governance practices such as; increased accountability, transparency, and, nurturing a meritocracy-based public service. Omoyefa (2008: 18) emphasizes the significance of the public sector reforms by arguing that the effectiveness and efficiency of the state can be measured through reforms in the public sector. It is therefore not a surprise that African governments were involved in formulation of policies to reform the public sector management and improve public service delivery. Mutahaba et. al. (2002), is cognizant that the developments witnessed in public reforms from the 1980 s, were a part of a global transition phase, both in the developed and the developing worlds.

Arguably, in most African countries, especially those that are considered to have been under the British sphere of influence, such as, South Africa, Nigeria and Kenya, the public sector was regarded as one of the key successes of the British colonial rule (Gboyega, 1989). Indeed, the earlier years of independence were characterised by better public service delivery and there was hope for greater socio-economic development because important steps were undertaken in the provision of social infrastructures and capital investments (Agagu, 2008: 247). However, few decades later, the state of public sector became far from what had 
been envisioned at independence. But, there were later significant pioneer postcolonial public sector reforms witnessed in the continent as consequences of the imposition of the Structural Adjustment Programmes (SAPs) by the World Bank during the 1980s (Mutahaba et. al, 1989) that involved the restructuring of the central administration systems in order to facilitate the proper management of state affairs for the benefit of the public.

Pollitt (2004: 883), argues that reforms in public sector are not necessarily new inventive ideas but rather, innovation that improves the already existing systems or at minimum, maintaining the structure but in a new environment of application. Additionally, this paper argues that the effectiveness of public sector reforms also depends to a very large extent, on how well it can integrate with the existing structure of power distribution and the economy. But, while Africa is still grappling with public service delivery due to the weak public sector, it is imperative to review what has been in existence in terms of public service delivery, the nature of the politics and economy. This provides a comprehensive understanding and allows development of sustainable solutions to the challenges facing the African public sector.

Foremostly, there is cognizance that, the general trend witnessed in Africa in public sector reforms has always been modelled to resemble the structure of public sector reforms undertaken in Europe (Kickert, 1997) as part of a bigger agenda of European governments to respond to changes in the society and address new challenges and rising needs of the public across the European continent. Foremostly, there is cognizance that, the general trend witnessed in Africa in public sector reforms has always been modelled to resemble the structure of public sector reforms undertaken in Europe especially in Britain during the 1970s under Margret Thatcher (Kickert, 1997) as part of a bigger agenda of European governments to respond to changes in the society and address new challenges and rising needs of the public across the European continent. Notably, these reforms were not only confined within Europe. Developing countries in Asia at the time, such as South Korea, Singapore and Malaysia, adopted extensive reforms in the public sector through approaches such as the New Public Management (NPM) that emphasized on re-organization and downsizing of the public sector, deregulation, nurturing performance management and increasing customer satisfaction as the key component of public sector management (Kim, 2000).

In Africa, the first comprehensive agenda for the establishment of public sector reforms were articulated by an economic World Bank report (Accelerated Development in Sub-Saharan Africa, 1981). According to Stockholm (2005), these reforms as demonstrated using the empirical studies on Zambia, Kenya, Uganda, Ghana and Tanzania, adopted the South Korean public sector restructuring model of the New Public Management.

Figure 1: Public Sector Reform Waves in Africa

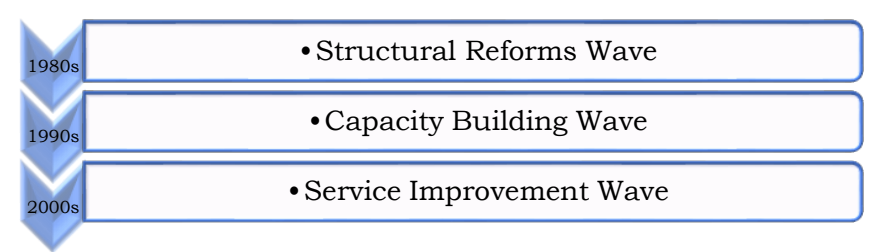

Source: Mutahaba and Kiragu (2002) 
The Structural Reform Wave in the 1980s, was adopted in the form of Structural Adjustment Programmes to address the macroeconomic and fiscal components of the African states that were undergoing through economic crisis. These reforms were sponsored by international institutions such as the International Monetary Fund (IMF) and World Bank and were meant to reduce the exorbitant government expenditures arising from the existence of a bloated work force that was chocking under corruption and low productivity.. Areas that had duplication of roles within the administrative structures were identified and a clear division of roles between the national governments, other local municipalities or federal states, private and humanitarian sectors were outlined. Primarily, the most important roles of the state were identified to be the provision of conducive environment that could support the growth of private sector; ensuring successful decentralization of public services; and, privatization, commercialization, or liquidation of non-functioning and loss-making public entities (Mutahaba and Kiragu, 2002).

The Capacity Building Wave from the 1990s, was developed as a response to the weaknesses and challenges observed from the structural adjustment programmes. The period that is also considered as the "lost decade" for Africa was characterized by a biting economic crisis following a bust in the prices of primary products that formed the backbone of African economies. Additionally, there were increasing public debts, high rates of unemployment, a rapidly expanding population, droughts and ethno-political conflicts. Ayee (2005) argues that these challenges were further compounded by politicization of the public sector through biased recruitment, bloated labour force, embedded corruption and unaccountability. These extensively impacted public sector delivery of goods and services. It therefore became necessary that reforms be instituted in the public sector to enhance efficiency and productivity through measures such as privatization of public companies, training of staffs to enhance their skills, improving the work environment to motivate staffs, enhancing the structures of management and, restoring work incentives through better pay or terms of service ((Stockholm, 2005).).

The Service Improvement Wave that is ongoing since 2000, represents the contemporary wave in sustained attempts to reform Africa's public sector and improve access and quality of public service delivery through administrative and political reforms. According to Karyeija (2012: 111), this wave focuses on the management techniques, budgetary and performance-based management to improve service delivery to the public. It is during this phase that the New Public Management has been adopted and does not fall short of demanding measures of transparency and accountability through a hands-on professional management that bestows responsibility on managers; emphasizes on public participation and engagement in decision making processes; demanding for timely results on delegated mandates from respective levels of leadership; and, the integration and adoption of a multi-sectoral approach to public service delivery. Moreover, this wave is connected to initiatives of poverty reduction measures through incorporation of various stakeholders in government strategic short-term and long-term development plans. According to Ayee (2008), the service improvement wave stresses on disciplined, effective and efficient use of public resources that maximises output of the public sector systems. 


\section{Discussion}

An analysis of World Poverty report (2019), indicates that $33.5 \%$ $(422,264,015)$ of the total population in Africa live in extreme poverty, indicating that Africa, more than half a century after attaining independence, continues to host several of the World's poorest countries. Moreover, Africa registers an average real income per capita of about $\$ 1,573.61$, which is at least 8 times lesser than the world average GDP income per capita (OECD, 2017). These statistics reflect the performances of African governments in improving the socio-economic development of African countries that formed the fundamental goal of public sector reforms. Despite the huge potential that the continent has in terms of natural and human resources, it is evident that the anticipated benefits of the public sector reforms are yet to be comprehensively effective so as to realise the real development needs of the African masses. Some scholars in analysing empirical findings of case studies within the continent, (Hope, 2001; 2000) hold that the public sector reforms have significantly improved service delivery in Africa while others (Schacter, 2000; Ayee, 2005) emphasize that the result have been largely unsuccessful if not negative.

In Ghana, the reform agenda under the Programme for Economic Recovery and Structural Adjustment initiated in 1983 saw government conduct a retrenchment in the civil service labour force that reduced government employees from 301,000 in 1986 to 260,000 by 1990 leading to an overall government wage bill decline of 4.5\% to the GDP (Antwi et. al., 2008: 255). Uganda also conducted radical reforms that reduced the government labour force by approximately more than 50\% (from 320,000 to 147,000) (Mwenda et. al., 2005: 453). Kenya and Zambia notably had different experiences from that of Ghana and Uganda. The retrenchment in Kenya was conducted on a voluntary early retirement programme while at the same time, the government embarked on recruitment of teachers thereby doing little in reducing the government wage bill (Rono, 2002: 84). In Zambia, implementation of the structural adjustment programmes begun much later in 1997 with the government retrenching approximately 37,000 workers in 3 years (Loxley, 1990: 15). According to Mutahaba et. al. (2002: 54) the structural adjustment wave had very little impact in improving service delivery in the public sector. Contrary to the expectations, the structural wave brought about incapacitation of the state in providing effective and efficient service delivery in the public sector because of the drastic reduction in the number of staff and absence of employment of new labour force to meet the demands of public development through skilled professional and technical labour in key sectors such as agriculture, health and education.

During the capacity building wave, the World Bank played a central role in providing assistance to African countries in both monetary and technical aid. The World Bank provided monetary credits for public sector reforms in countries such as Kenya (1994), Uganda (1995), Ghana (1995) and Tanzania in 1999 (Moussa, 1992: 1737-42). Additionally, other international institutions such as the United Nations Development Programme, United Kingdom and the Swedish Development Agency offered support in different capacities to African countries to enhance capacity-building in the public sector. However, the capacity building wave did little to incentivise the already demoralized public sector work force due to the lack of better pay reforms that is critical in sustaining the progress of capacity building. The resources obtained from the retrenchment of workers during the structural adjustment programmes were limited to adequately improve the low salaries of public servants. Consequently, despite the reforms intending to increase capacity in the public sector, corruption and other unethical conducts 
became embedded in the public thereby leading to further deterioration of public services.

The service improvement wave which has been on-going since 2000 has focused on public service performance by among other indicators emphasizing on achievement of yearly organizational goals of the public sector. Managers have become increasingly accountable to the public and government through annual audits on performance and use of public resources. Notably, this phase despite maintaining consistency, the progress remains relatively slow because of the low implementation capacities that still face African countries and the low wages of public employees. Nonetheless, this phase is presenting a unique opportunity to bring into account all public employees and embed more transparency in the public sector.

In light of these dynamics, this paper argues that in as much as there have been significant public sector reform gains in the continent, the attainment of sustainable development in the public sector demands more efforts and collaboration within the African continent. By examining the trends in public sector reforms, this paper identifies key issues that emerge from the African experience. These include: public sector reform outcomes are gradual and take time to transform into real experiences that can improve public service delivery; that the success of public sector reforms depends on unreserved political-will and public support; and, that corruption has a big impact in public sector reforms in Africa.

According to Hayden (200: 133), political support is crucial to the success of public sector reforms. This is because structural reforms that may for instance, require reduction of labour in the public service through entrenchment may be subjected to intense politicization. It is therefore imperative that the political elites provide strong leadership to enable the full implementation of public sector reforms. Moreover, the civil society need to be included in the processes involved in public sector reforms. This sis because the civil society have the capacity to influence the implementation of such reforms either as proponents or opponents through judicial systems (Robinson, 2004: 34). Additionally, Schacter (2000: 3) argues that the reforms in the public sector should be advanced by local stakeholders both within and outside the confines of the public sector. As such, the success of public sector reforms is dependent on the cooperation of the political elites and the bureaucrats in the sector.

The contemporary reforms in the public sector are influenced by the public sector management challenges such as: inability of many African governments to meet annual budgetary needs and incapacity of governments to adequately respond to rising public service needs due to the rapidly changing dynamics of the continent (ECA, 2010; UNECA, 2004; AFDB, 2005). Addressing these issues is fundamental to the efforts of long-term development and reduction of poverty rates in the society (Ayee, 2008) through provision of better public service. However, these reforms are not immune to challenges. The public sector management continue to face challenges that significantly reduce the quality of service delivery, scope and speed of reforms. Among these are issues of rapidly declining ethics in public service provision, depleting social value and civil service morale, weak institutional capacities and duplication of roles which only leads to unaccountability due to blame games and corruption. 


\section{Public Sector Reform Challenges: Corruption and Weak Governance}

This paper identifies corruption and weak governance as the key challenges that continue to face the effectiveness of the public sector reforms in the continent. This is because of their overreaching negative influences on the previous gains made in the public sector reform waves and contemporarily on the political stability and economies of African states. According to McCormack (1997), corruption in the public sector allows for deviation from sanctioned ethical behaviours by public officers because of their status and therefore, increases the costs of the public services needed by the citizens. Whereas service delivery. Nonetheless, this paper recognizes the efforts of African governments have taken measures to address the issues of corruption through legislation of AntiCorruption bills, establishing offices such as the Ombudsman office and other institutions of ethics and anti-corruption. The concern about the negative impact of corruption was reaffirmed for instance in 2018, when the African Union in its wisdom, declared the year's theme to be, "Winning the Fight against Corruption: A Sustainable Path to Africa's Transformation (AU, 2018)"

Despite the corruption scandals that have been rocking the continent through the years, the corruption index report for the year 2018, establishes an array of hope in parts of the continent. This is because model African countries such as Rwanda (55\%) and Cape Verde (55\%), have illustrated that with proper motivation and commitment, corruption can be tamed and managed with sustained efforts. Other countries such as Botswana (60\%), Seychelles (61\%) and Namibia have shown great efforts in anti-corruption war that sees them rank higher in the corruption perception index than some of the developed countries in the OECD zone such as Spain (57\%) (Transparency International, 2018).

Figure 3: Global Corruption Perception Index

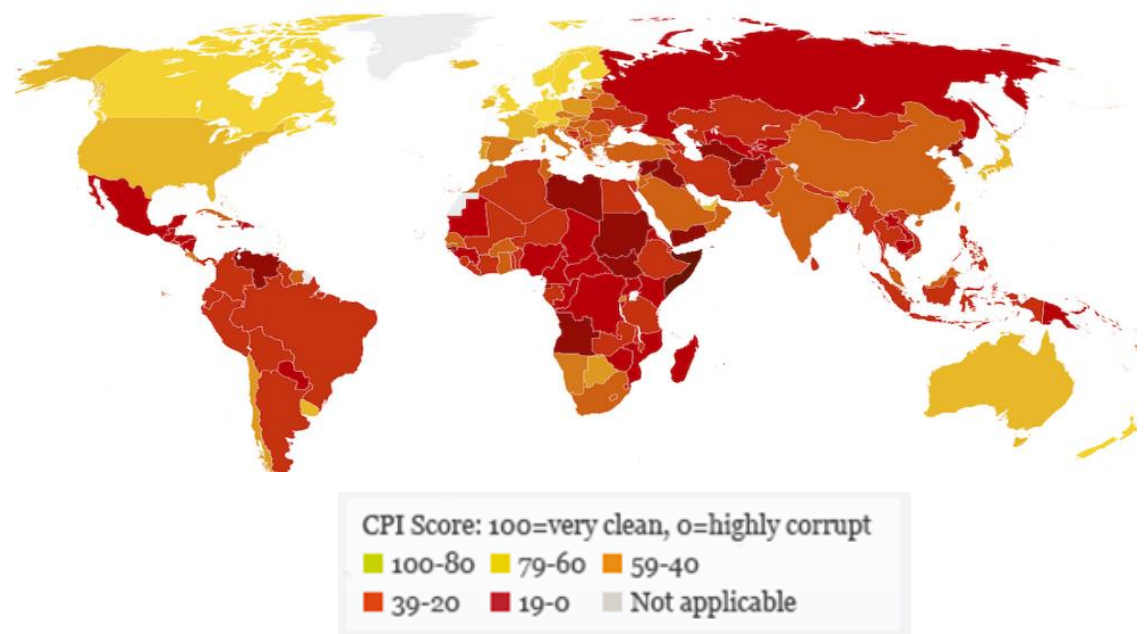

Source: Transparency International, 2018 
Rwanda for instance have taken deliberate measures to enforce compliance of leadership codes, Cape Verde have adopted open promotion of institutional transparency while Botswana have taken the path of innovative approach on mainstream anti-corruption campaigns. In all these improved African countries, the public has witnessed better public service provision and as such, confirming the hypothesis that the absence of corruption enhances better public service provision.

Figure 4: Africa: Rule of Law Indicators and Average Trends (2013-2017)

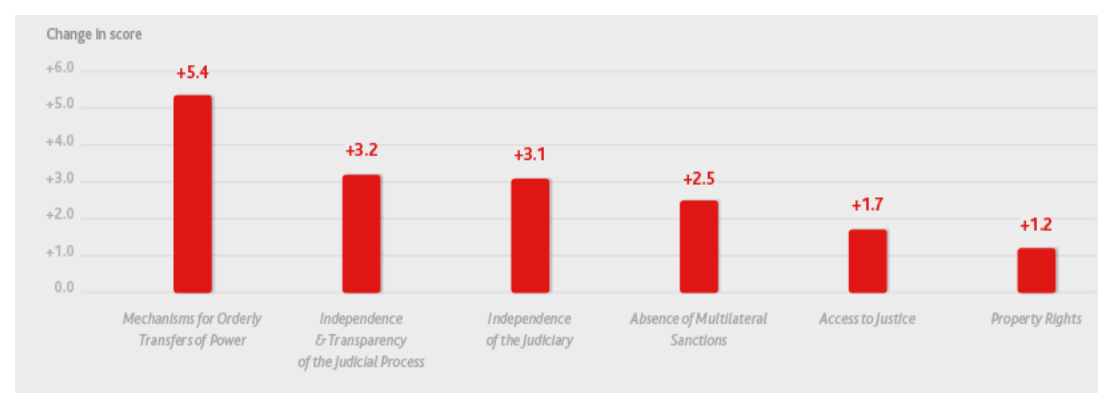

Source: Ibrahim Index of African Governance (2018)

Additionally, a report by Ibrahim Index of African Governance between 2013-2017 on transparency and accountability, emphasizes on the need to consolidate these small gains made towards improving the overall governance on the continent. The report also established that eight of the top ten scoring countries in better governance in Africa featured in the leading countries in terms of the rule of law, transparency and accountability.

\section{Recommendations: Strengthening Africa's Political Economy}

The effectiveness of a stronger and efficient public service cannot be conceived outside the precincts of the wider political economy. This is because elements of land, capital, labour, commodity, value, utility and wealth with which political economy is concerned with, are the basis of public service delivery mechanisms and approaches. More comprehensively, political economy entails the conditions of production structure in states through establishing a link between politics and economics, which are constitutive of development or underdevelopment.

Extensive documented literature and debates have constantly tagged Africa as being marginalised in the global economic system and more often than not, the poverty experienced in several parts of the continent have been extensively attached to this concept of marginalization (Mlambo, 2006; Lawal, 2006; Nwankwo, 2000). This paper is critical to these this view and instead, argues that Africa is very much integrated into the global economic system than any other developed or developing region. Indeed, it is not contestable that through consideration of economic indicators such as the gross domestic product, Africa holds the mantle of the poorest continent. However, the quantity of imports and exports of the African market are illustrative that the global market system is one that does not strive to maximise productivity but rather, it is a system that prefers emphasizes on conditions of production that maximizes the rates of profitability. As such, instead of assuming the position of a marginalised continent, Africa remains at the centre of global economic system but as an actor that is continuously exposed to extreme exploitation in an exploitative international 
political economy environment. These dynamics therefore deprives Africa the much-needed resources required to sustain public sector development.

Figure 6: Average Annual Percentage Growth Rate Of GDP Per Capita In Sub-Saharan Africa (1970- 2019)

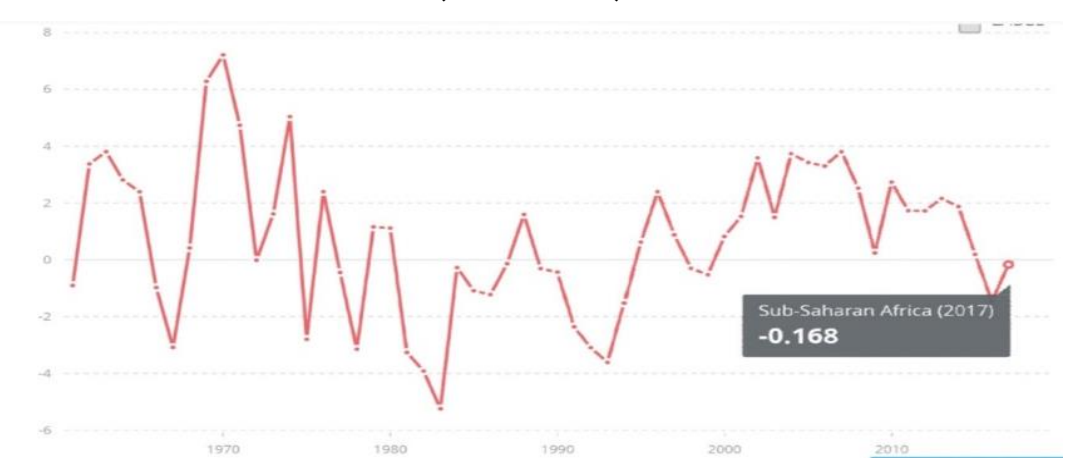

Source: World Bank (2019) national accounts data, and OECD National Accounts data files.

With Africa posting negative annual average GDP per capita growth in 2017 , the question that lingers is how the continent can escape from exploitation and harness the true potentiality of its political economy. From ancient civilizations that dominated and shaped world history, to the modern day developed states, the commonality is that they were all founded and sustained on auto-centred economies. More comprehensively, these economies were open and therefore, Africa's political economy needs to embrace this attribute. More importantly, contemporary debate on Africa must not only emphasize on marginalization which only tends to discuss the question of 'in which ways' and not 'to what extent', is the continent integrated in the global capitalist system.

According to Pierre et. al. (2000: 41), the means by which governments choose to govern not only affect policy outcomes, but also has significant real effects on the society and economy. For instance, there is significant amount of evidence within the Sub-Saharan African region that, governments prefer to spend on targeted programmes such as government jobs to reward political cronies or infrastructural investments that provide avenues for the embezzlement of public resources rather than improve public service delivery. Feyzioglu, et. al. (1998: 33), argues that for instance, foreign aid meant for the education sector may result in decreased budgetary allocation by the government for the provision of this service. On the contrary, when aid is used to support public infrastructure investment such as in the sectors of transportation and communications, African governments are more likely to maintain their own fiscal allocations because infrastructural developments have become the new avenues for grand corruption schemes in the continent through secretive tender deals that are shrouded in secrecy between a few high-ranking individuals in the government and the private sector.

Moreover, improved public service delivery requires significant financial resources which is not easily accessible to several African countries. A majority of African governments are either frozen out of the global financial system or been granted limited access to financial resources. This is partly because of reckless borrowing and mismanagement of funds through corruption by the political elites, high-government officials and their co-conspirators in the private sector. Certain countries like Cape Verde (129.7\%), The Gambia (120.2\%), Republic of Congo $(117.7 \%)$ and Mozambique $(112 \%)$ having very high public debts relative to their 
GDP (The Economist, 2018), continue to struggle to properly service existing loans. Therefore, unable to borrow, investments in public sector through construction of roads, ports, schools and provision of healthcare services have become untenable. Zambia for instance, has a higher expenditure on debt servicing than on education (The Economist, 2018).

Figure 7: Sub-Saharan Africa Public Debt (1976-2016)

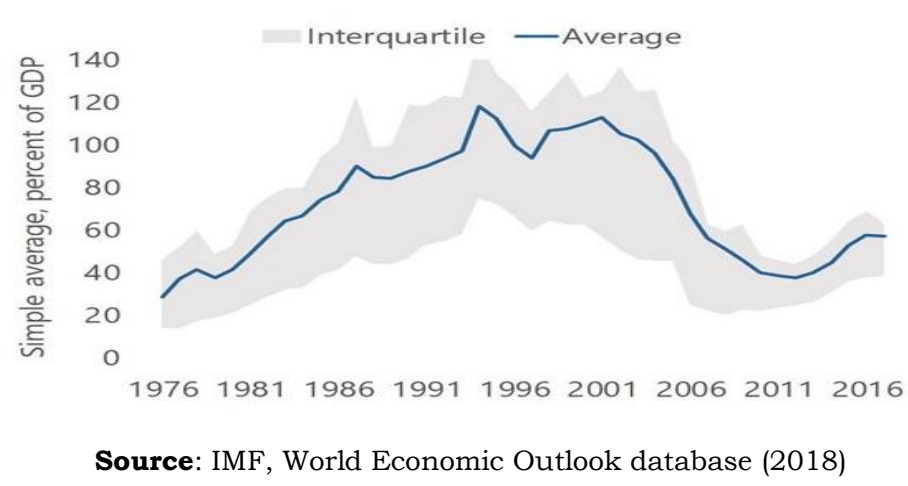

In 2013-16 the ratio of public debt to GDP in sub-Saharan Africa, as defined by the IMF, increased by an average of five percentage points a year for countries that do not produce oil, and eight for those that do. It is now above $50 \%$ in half of the countries in the region.

\section{Political Decentralization}

This paper focuses on the role of administrative decentralization because of its capacity to address challenges in decision-making processes, ineffectiveness and accountability which impact the capacity and quality of the public sector. It also addresses the questions of marginalization as remote areas become represented and included in the development of the public sector. Genuine efforts of decentralization also encourage participation of the public and extensively minimises the imbalance of power. Girinshankar et. al (2000), argues that this reduced imbalance of power encourages the contribution of the ordinary public to shape their institutions of public service delivery. Thus, enabling them to include their preferences in public policy. Alternatively, this understanding is reflective of the ability of decentralization to complement the continuing democratic reforms in Africa. Administrative decentralization establishes division of labour such that the high-ranking public employees can concentrate in the facilitation of facilitating local government services, establishing standards and local regulations, offering capacity building through training of employees in the devolved levels, and, providing rewards and penalties to improve local government perform.

The local devolved units become entrusted with the tasks of hiring, paying, and sanctioning all those who are mandated with provision of public goods and services at the lowest devolved levels (World Bank, 2000b). The consequence of such realignments is that administrative decentralization enhances the quality and quantity of productivity of both the local and central administration due to specialization. Additionally, by distorting the face-to-face encounter between the top political executive and bureaucrats, the basis of the rent-seeking culture and exclusion which hampers the provision of public services will be significantly weakened. 
In the long-term, administrative decentralization may be the solution that addresses the challenges that threaten democracy such as ethnicity which is rife within the continent. Several scholars (Dasgupta et. al, 2000; Colletta et. al, 2000) identify other challenges in the African public sector such as nepotism, corporatism and regionalism that stem from the appropriation of social capital for inappropriate purposes. Employment in post-colonial Africa has been so much attached to ethnicity to the extent that sound competition and meritocracy are conspicuously absent in the public sector. Therefore, decentralizing the public sector service provision may transform these trends not because competition would be drawn from the same region or ethnic group, but rather because the competition would occur in an environment where actors would be exposed to more scrutiny and accountability by the local public regarding their responsibilities. Decentralization of public service delivery therefore instead of nurturing ethnicity, it brings the different stakeholders to interact on a platform founded on familiarity and trust thereby improving the stock of social capital.

\section{Conclusion}

Africa has been under pressure since the closure of the 1980s from OECD member states and the World Bank who continue to emphasize the essence of good governance as the prerequisite for sustainable development. This version of good governance is tantamount to improve public sector institutional reforms using models that have been tested and proved in the developed countries. However, analysis of the subsequent success in growth spurred by reforms in the public sectors in the East (China and Vietnam) and South East Asia (South Korea, Singapore and Malaysia) which were attained without strict adherence to the Western 'best practices' (Samaratunge et. al., 2008), demonstrates that majority of these regions sustained growth that was oriented towards empowering the public unlike the structural adjustment programmes and capacity reforms that focused only on public sector management and not productivity of the masses. Unlike in the African experience, Indonesia, Malaysia and Vietnam invested heavily in rural development guided by urgency, outreach and expediency for improved public service provision (Henley et. al., 2010). A report by Africa Power and Politics (2012), criticised the African approach to public sector reforms by arguing that the success of these reforms is not question of countries complying with the ideals of good governance, but rather, how the political elites and other stakeholders respond to the choices about policies and policy implementation. These two important issues are concerned with governance and institutions but not 'good governance'. It is even less concerned about the formal structures of governments, parties and elections, and more about informal aspects of the way decisions are made and actions taken at all levels of the political system and society. In as much as economic transformation may not mandatorily require good governance, this paper asserts that it is an important requirement that governments make substantive commitments to good governance practices.

From the analysis provided herein, it is therefore deduced that reducing poverty rates in Africa require effective service delivery foremostly within the framework of the available resources. This means that issues that relate to corruption or bad governance must be addressed. Secondly, political decentralization is key because it promotes the integration of territories that are otherwise alienated from the central government and which undermine the efforts of central government to deliver public services effectively in the remote areas. Additionally, African institutions must be strengthened because they form part of the public service delivery systems. The absence of accountability has for the longest time hampered any good governance of public resources that ought to 
enhance the access and, or quality of public services delivery through the system of rents that accounts for the distortions in service delivery processes. Addressing these issues will be key in the efforts to reduce the widespread cases of poverty. But even more importantly, based on the nature of the required reforms, adequate preparations through stipulated frameworks ought to be done as there is always a tendency of rebellion from politically powerful classes who may be at risk of losing their interests.

\section{References}

Adegoroye, G (2006). Public Service Reform for Sustainable Development: The Nigeria Experience. Keynote address delivered at the Commonwealth Advanced Seminar, Wellington, New Zealand.

AFDB. (2005). Africa Development Bank Report 2005: Public Sector Management in Africa. Oxford/New York: Africa Development Bank.

Agagu, A.A. (2008). Re-Inventing The Nigerian Public Service In An Age Of Reforms. Pakistan Journal of Social Sciences, 5(3), 243-252.

Antwi, K. B., Analoui, F. and Nana-Agyekum, D. (2008). Public Sector Reform In Sub-Saharan Africa: What Can Be Learnt From The Civil Service Performance Improvement Programme In Ghana?. Public Administration and Development: The International Journal of Management Research and Practice, 28(4), 253-264.

Ayee, J. R. A. (2008). Reforming The African Public Sector: Retrospect And Prospects. Dakar: CODESRIA

Bates, R. and Devarajan, S. (1999). Framework Paper On The Political Economy Of African Growth. Mimeo,

Colletta, N. J. and Cullen, M. L. (2000). Violent Conflict And The Transformation Of Social Capital. Washington DC: The World Bank.

Corkery, J, T.O. Daddah, C. O'Nuallain and Land, (1998). Management of Public Service Reform: A Comparative Review of Experiences in the Management of Programmes of Reform of the Administrative Arm of Central Government, International Institute of Administrative Sciences, Brussels: IOS Press.

Dasgupta, P. and Serageldin, I. (2000). Social Capital. A Multifaceted Perspective. Washington DC: The World Bank.

Deng, F. M. (2001). Ethnic Marginalization As Statelessness: Lessons From The Great Lakes Region Of Africa. Citizenship Today: Global Perspectives and Practices, 183-208.

Economic Commission for Africa (ECA). (2004). Public Sector Management Reforms In Africa. Addis Ababa: Economic Commission for Africa.

Economic Commission for Africa (ECA). (2010). Innovations and best practices in public sector reforms: The case of civil service in Ghana, Kenya, Nigeria and South Africa. Addis Ababa: Economic Commission for Africa.

Farazmand, A. (1999). Globalization And Public Administration. Public Administration Review, 509-522. 
Feyzioglu, T., Swaroop, V. and Zhu, M. (1998). A Panel Data Analysis Of The Fungibility Of Foreign Aid. The World Bank Economic Review, 12(1), 29-58.

Forbes Magazine, (May 2001), Africa and Economics https://www.forbes.com/global/ 2001/0528/046.html\#495addb977cd

Garnham, N. (1990). Public Policy And The Cultural Industries. Capitalism And Communication: Global Culture And The Economics Of Information, 154168.

Gboyega, A. and Abubakar, Y. (1989). Introduction: The Nigeria Public Service In Perspective. In A. Gboyega, A; Abubakar, Y and Aliyu, Y (Eds). Nigeria Since Independence: The First Twenty-Five Years, Vol III. Public Administration, Ibadan: Heinemann Educational Book Ltd.

Girinshankar, N. and Levy, B. (2000). Addressing Governance and Institutional Issues in the Poverty Reduction Strategy Process. An Approach for Country Teams in the Africa Region. Draft, Washington DC: The World Bank.

Gordon, D. F. (1996). Sustaining Economic Reform Under Political Liberalization In Africa: Issues And Implications. World Development, 24(9), 1527-1537.

Haque, M. S. (2001). The Diminishing Publicness Of Public Service Under The Current Mode Of Governance. Public Administration Review, 61(1), 65-82.

Henley, D. and Leiden, K. I. T. L. V. (2010, May). Three Principles Of Successful Development Strategy: Outreach, Urgency, Expediency. In 3rd Plenary Tracking Development Conference, 11-14.

Ibrahim Index of African Governance (2018), http://mo.ibrahim.foundation /news/2019/rule-law-transparency-accountability-key-improving-publicgovernance-africa/

IMF, World Economic Outlook database (2018), The Debt Challenge to African Growth, https://www.imf.org/en/News/Articles/2018/07/31/vc052318the-debt-challenge-to-african-growth.

Karyeija, G. K. (2012, March). Public Sector Reforms In Africa: What Lessons Have We Learnt?. In Forum for Development Studies, 39(1), 105-124.

Kickert, W. J. M. (Ed.). (1997). Public Management And Administrative Reform In Western Europe. Edward Elgar Pub.

Kim, S. (2000). Reform Efforts Toward New Public Management In Korea. A Paper Presented At IIAS/Japan Joint Panel In Public Administration. Italy: Bologra.

Laumann, E. O. and Knoke, D. (1987). The Organizational State: Social Choice In National Policy Domains. Univ. Of Wisconsin Press.

Lawal, G. (2006). Globalisation And Development: The Implications For The African Economy. Humanity And Social Sciences Journal, 1(1), 65-78.

Loxley, J. (1990). Structural Adjustment In Africa: Reflections On Ghana And Zambia. Review of African Political Economy, 17(47), 8-27.

McCormack, R. (1997) International Corruption, A Global Concern, Paper presented to the International Anti-Corruption Conference, Peru.

Mlambo, A. S. (2006). Western Social Sciences And Africa: The Domination And Marginalisation Of A Continent. African Sociological Review, 10(1), 161-179. 
Moussa, A. and Schware, R. (1992). Informatics in Africa: lessons from World Bank Experience. World Development, 2O(12), 1737-1752.

Mukandala, R. (2000). To Be Or Not To Be: The Paradoxes Of African Bureaucracies In The 1990s. African Public Administration: A Reader, Harare, AAPS Books.

Mutahaba, G. and Balogun, J. (1989). Enhancing Management Capacity in Africa. West Hartford: Kumarian Press

Mutahaba, G. and Kiragu, K. (2002). Lessons of International and African Perspective on Public Service Reform: Example from Five African Countries. African Development, 27(3-4), 48-75.

Mwenda, A. M. and Tangri, R. (2005). Patronage Politics, Donor Reforms, And Regime Consolidation In Uganda. African Affairs, 104(416), 449-467.

Nwankwo, S. (2000). Assessing The Marketing Environment In Sub-Saharan Africa: Opportunities And Threats Analysis. Marketing Intelligence \& Planning, 18(3), 144-153.

Olagboye, A.A. (2005). Inside the Nigerian Civil Service. Ibadan: Daily Graphics Ltd

Olowu, D. (1992). Roots And Remedies Of Governmental Corruption In Africa. Corruption and Reform, 7(3), 227-236.

Omoyefa, P. S. (2008). Public Sector Reforms In Africa: A Philosophical ReThinking. Africa Development, 33(4).

Pierre, J. (Ed.). (2000). Debating Governance: Authority, Steering, And Democracy. OUP Oxford.

Pollitt, C. and Bouckaert, G. (2004). Public Management Reform: A Comparative Analysis. USA:Oxford University Press.

Rono, J. K. (2002). The Impact Of The Structural Adjustment Programmes On Kenyan Society. Journal of Social Development in Africa, 17(1), 81-98.

Samaratunge, R., Alam, Q. and Teicher, J. (2008). The New Public Management Reforms In Asia: A Comparison Of South And Southeast Asian Countries. International Review of Administrative Sciences, 74(1), 25-46.

Schacter, M. (2000). Public Sector Reform In Developing Countries: Issues, Lessons And Future Directions. Ottawa: Canadian International Development Agency.

Stockholm, M. (2005). New Public Sector Management in Africa. African Development, Special Issue, (3\&4)

Tarrow, S. (2013). Contentious Politics. The Wiley-Blackwell Encyclopedia of Social and Political Movements.

Thomas, M. and Barkan, J. 1998. Corruption and Political Finance in Africa. Mimeo, PREM Unit, Washington DC:The World Bank.

UNECA. (2004). Public Sector Management Reforms: Lessons Learnt. Addis Ababa: UNECA Press

World Bank (2000b). The Community Driven Development; From Vision to Practice. A Technical Book. Africa Region, The World Bank, Washington DC. 
World Bank (2019), National Accounts Data, and OECD National Accounts Data Files. https://data.worldbank.org/indicator/NY.GDP.PCAP.KD.ZG?end= 2017\&locations $=$ ZG-KE\&start $=1961 \&$ view $=$ chart 